\title{
The Local Authority Of Java Communities In Serat Pikukuh
}

\author{
Yohanes Suwanto ${ }^{1}$, Dyah Padmaningsih ${ }^{2}$, Sundari ${ }^{3}$, Endang Tri Winarni ${ }^{4}$ \\ \{1yswan2001@yahoo.com, 2dyahpadmaningsih@yahoo.co.id, \\ ${ }^{3}$ sundari@staff.uns.ac.id, ${ }^{4}$ et_windy@yahoo.com $\}$ \\ 123 Regional Literature Study Program, of Culture Faculty, \\ Sebelas Maret University of Surakarta
}

\begin{abstract}
This article is entitled: Local Wisdom of Javanese Communities in Serat Pikukuh (Ethnolinguistic Research). This article describes verbal expressions, especially with regard to local wisdom in the Serat Pikukuh. Pikukuh (Serat Pikukuh) here is a land and / or building certificate during the Surakarta Keraton and Mangkunegaran Temples that used Javanese with Javanese letters, so to reveal the types of local wisdom must be transcribed from Javanese with Javanese letters into Javanese Latin letters. The aim of this research was to document the types of local authority and verbal expression of local wisdom of the Javanese people in Serat Pikukuh. This local authority research uses descriptive qualitative methods with ethnolinguistic analysis models to classify types of local authority and identify verbal expressions of local wisdom written in Serat Pikukuh, the data of this study are written data. Data collection with library techniques. Data analysis was carried out using ethnocentric analysis models (taxonomic analysis, componential analysis, domain analysis) which are relevant to analyzes based on cultural themes. The cultural themes in question concern the category and expression of language and culture of Serat Pikukuh as a reflection of local authority.Based on the data analysis, it can be concluded that (1) local authority of Javanese people in Serat Pikukuh can be divided into local authority in law, local authority of ethics / manners, local authority in the social field, local authority in the field / land location, local authority of agricultural produce, and local authority in the tax sector; and (2) local authority in Serat Pikukuh is very beneficial for the community, especially the Javanese community, which will increasingly raise awareness in social and national life in the fields of law, ethics, social, and awareness of paying taxes.
\end{abstract}

Key words: local authority, Javanese society, serat pikukuh, and ethnolinguistics.

\section{Introduction}

Pikukuh (Serat Pikukuh) (it will be abbreviated as SP) is a land and building certificate in royal times which used Javanese and written in Javanese letters. Pikukuh contains Javanese speech as a legacy from the ancestors for the next generation which is almost forgotten. This is 
caused by the lack of mastery of the Javanese language, even Javanese written in Javanese letters [1]. For example, data found from Javanese letters that have been translated into Latin Latin language as follows.

\section{PIKUKUH ANGKA: 335}

Abdi Dalem Bupati Patih Mangkunagaran, sawuse anguningani lan anggalih proses perbaling komisi utusane nagara, katitimangsan surya kaping 7 Mei 1934 kang dilempirake layange bupati pangreh praja ing Kutha Mangkunagaran, katitimangsan surya kaping 15 Mei 1934, angka 820/31, sarta sawuse aniteni surasane layang dhawuh pranatan katitimangsan tanggal kaping 28 Mulud Be 1848, utawa surya kaping 12 Januwari 1918, angka 1/R lan katitimangsan tanggal kaping 26 Jumadilakir 1848, utawa surya kaping 9 April 1918, angka 6/R anamtokake kaya ing ngisor iki.

1. Amaringi lilah marang Somowirono ..................... yen wiwit ing surya kaping $\mathbf{1}$ Januwari 1900 telung puluh papat, kaparengake anggadhuh papan pomahan ing kampung Gondhang (Manahan), bawah kapanewon lan kawadanan pangreh praja Kutha sarta Kabupaten ing Kutha Mangkunegaran, ukuran ambane $354 \mathrm{M}^{2}$ (Telung atus seket papat)....... meter pasagi) kaya kang kasebut ing gambar kang kaganthetake ing layang pikukuh iki, mungguh panggadhuhe pomahan mau, kajaba yen ana sababe $[\ldots]$ kaparingake gumadhuh ing salawase.

\section{'PIKUKUH NUMBER: 335}

Abdi Dalem Bupati Patih Mangkunagaran, setelah mengetahui dan menimbang proses verbal komisi utusan negara, tanggal 7 Mei 1934 yang dilampiri surat bupati pangreh praja di Kota Mangkunagaran, pada tanggal 15 Mei 1934, nomor 820/31, serta setelah mengetahui isi surat peraturan tanggal 28 Mulud, Be 1848, atau tanggal 12 Januari 1918, nomor 1/R lan tanggal 26 Jumadilakir 1848, atau tanggal 9 April 1918, nomor 6/R menetapkan seperti sebagai berikut.

1. Memberi izin kepada Somowirono ........................ bahwa sejak pada tanggal 1

Januari 1934, diizinkan menggaduh pekarangan di kampung Gondhang (Manahan), di bawah kapanewon pangreh praja Kota, serta Kabupaten ing Kota Mangkunagaran, ukuran luasnya $354 \mathrm{M}^{2}$ (Tiga ratus lima puluh empat meter persegi) seperti yang tersebut pada gambar yang disatukan pada surat pikukuh ini, tentang hak menggaduh perumahan tersebut, kecuali jika ada sebab lainnya diberikan hak menggaduh untuk selamanya.

$[\ldots]$ '

The data above is originally Javanese written in Javanese letters, and has been transcribed into Javanese Latin letters. The Pikukuh numbered: 335. The data shows verbal expressions of Javanese that contain local wisdom, especially Javanese people. Based on the verbal expression was carried out by Abdi Dalem who already knew and was based on consideration of the verbal process by the commission. Based on the verbal expression in the data, it shows that there is a careful action, which is 'reporting' in lingual unit of layang paturane 'report letter' and 'affirmation' action in lingual unit Anggalih ora ana pakewuhe panyuwunan mau kaparengake 'Considering that there is no problem the request is granted'. Likewise, there is a wisdom to permit zin to Somowirono to disturb 354 M2 land as shown in the data: Amaringi lilah marang Somowirono ...................... yen wiwit ing surya kaping 1 Januwari 1900 telung puluh papat, kaparengake an ggadhuh papan pomahan ing kampung Gondhang (Manahan), bawah kapanewon lan kawadanan pangreh praja Kutha sarta Kabupaten ing Kutha Mangkunegaran, ukuran ambane $354 M^{2}$ (Telung atus seket papat)...... meter pasagi) [...] 'Giving permission to Somowirono that since on January 1, 1934, it 
was permissible to row the yard in Gondhang (Manahan) village, below when the municipal pangreh praja Kota, as well as District at Mangkunagaran City, the size of the area of 354 M2 (Three hundred and fifty four square meters) [...] 'Thus, the pikukuh fiber as a document and means of linguistic communication contained local wisdom (local genius) ).

As explained in the background of the problem, that pikuh fiber as a certificate of ownership of land and / or buildings issued by the Surakarta Palace and Mangkunegaran Temple is a phenomenon of using language containing local wisdom which is very interesting to study so that it can reveal the legacy of the previous generation and can be utilized by students and the community, its owner community, and the government.

The urgency of the object of this study was chosen (a) practically the results of this study are expected to be beneficial for: (1) the next researcher as a reference material for similar research; (2) the community can understand the Javanese local wisdom in pikukuh fiber as a local cultural property; (3) the government, the need for this research to enrich the documentation of land and / or building certificates in royal times, bearing in mind that pikukuh is a valid proof of ownership so that it is useful in transferring ownership rights; (b) theoretically can add ethnolinguistic theory.

This research is very important to do because so far the search that has been done has not found the results of research related to local wisdom in pikukuh fiber. Therefore, this research was conducted with the title: Local Authority of Javanese Communities in Serat Pikukuh (Ethnolinguistic Research).

\section{Research Methods}

This research method includes three stages, namely (1) the stage of providing data, (2) the stage of data analysis, and (3) the stage of presenting the results of the analysis [2].

\section{a. The Location of this Research}

The activity of this research took place in the city of Surakarta and its surroundings. This location was deliberately chosen because the Surakarta area and its surrounding community mostly still have pikukuh fibers as a hold of land / yard and / or building ownership rights which were under the authority of the Surakarta Palace and the Mangkunegaran Temple in Surakarta.

\section{b. Methods and Techniques for Data Providing}

In providing this research data, use the refer method. Researchers listened to the use of language in pikukuh published by the Surakarta Palace and Mangkenegaran Temple of Surakarta. The issue was in the form of Serat Pikukuh written in Javanese letters and Latin letters in Dutch. From this pikukuh data will be obtained in the form of local wisdom types and functions of local wisdom in Serat Pikukuh as the object of research [3]. After scanning by identifying research data, data transcription, translation, data recording, data classification, and data analysis are then carried out [4]. The data classification and analysis was carried out in accordance with the objectives of the study, namely to find out the type of local authority in Serat Pikukuh and the function of local authority in Serat Pikukuh for Javanese people [5].

c. Methodology of Data analysis

This data analysis method involves the analysis of the types and functions of local authority in Serat Pikukuh. 
1) Determination of the type of local authority in Serat Pikukuh.

Determination of the type of local authority in Serat Pikukuh by descriptive method. The basic technique is the sorting technique, which is that all types of local authority obtained from the library are sorted, and the follow-up technique is note taking.

2) Determination of the function of local authority in Serat Pikukuh

Determination of this function is done by analyzing the data carried out by ethnographic analysis models (taxonomic analysis, componential analysis, domain analysis) that are relevant to analyzes based on cultural themes. The cultural themes in question concern the category and expression of language and culture of the Pikukuh Fiber as a reflection of local wisdom. Ethnoscience has the understanding of knowledge possessed by a nation more precisely certain ethnic groups or social groups [6]. The follow-up technique with content analysis.

As explained in the background of the problem, that Serat Pikukuh as a certificate of ownership of land and / or buildings issued by the Surakarta Palace and Mangkunegaran Temple is a phenomenon of language use (especially verbal expressions) very interesting to study so that it can reveal the legacy of previous generations and can be utilized by students and the community, their owner communities, and the government (specifically the BPN or the National Land Agency).

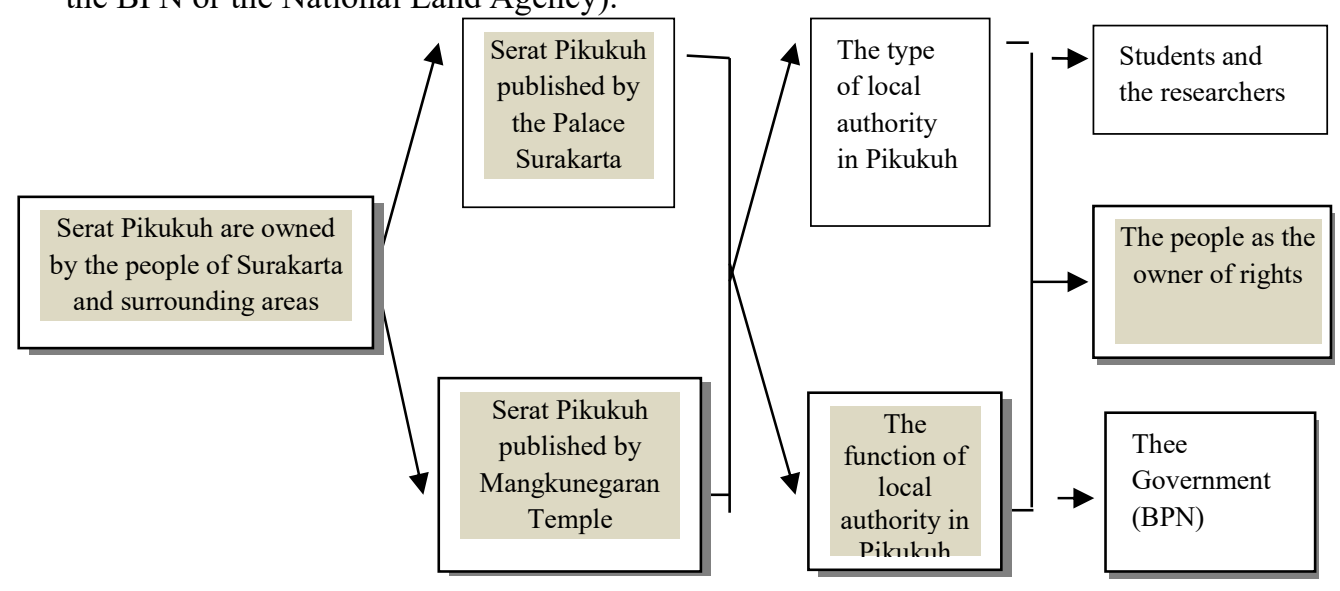

\section{d. Method of Presentation of Results}

The results of the analysis in the form of rules can be presented in two ways, namely (1) formulation with ordinary words and (2) formulation using signs or symbols. The first is often called the informal method and the second is often called the formal method. The use of words or symbols is a technique of presenting the results of the analysis. 


\section{Results And Discussion}

Based on the analysis of data that has been carried out on the SP, it can be seen the existence of local authority types and the benefits of the Javanese people [7].

a. Types of Local Authority in SP

1) The authority in law

Local authority in the field of law in the SP expressed with verbal expressions as follows.

\section{PIKUKUH}

Angka: 20/1 B.

Pepatih ing Karaton Dalem Surakarta Hadiningrat, terang kauningan Sampeyan Dalem Ingkang Sinuhun Kangjeng Susuhunan.

Angengeti layang pranatan kang kapacak ing layang kabar nagara, angka 18, taun 1918, sarta kang kapacak ing layang kabar nagara angka 4, taun 1919, bab 1, adeg-adeg 2, anguningani:

Layang paturane bupati Kutha Surakarta katitimasan kaping 19 Pebruwari 1920 Angka 913/2B kanthi layang pratandha anggone Trunadikromo A. wus anglilakake wawenang panggadhuhe palemahan ing Kampung Tipes sakarangkitrine marang Pododikromo anggadhuh palemahan kagungane nagara ing Kampung Tipes

Anggalih ora ana pakewuhe panyuwunan kasbut ing dhuwur kaparengake.

Ing mengko manira anglilani marang: Pododikromo.

Wawengkon Kalurahan Tipes

Onderdhistrik Serengan

Dhistrik Kutha, Kabupaten Surakarta

Jembare 679 meter pasagi, kaya kang kapetha ing layang ukuran kang kaganthet ing layang pikukuh iki, mawa janji-janji kang wus kapacak utawa bakal kapacak ing layang-layang pranatane nagara ingatase prakara pomahan sajroning nagara Surakarta.

Layang pikukuh iki kaparingake Pododikromo minangka pikukuhe gone anggadhuh palemahan mau.

Dhawuhing pikukuh tanggal kaping 30 Maret 1921.

\section{PIKUKUH}

Angka: 20/1 B.

Train at the Royal Palace of Surakarta Attendance, knowing that you are at the forefront of investment.

Considering the regulatory letter contained in the state newspaper, Number: $18 ; 1918$, as well as in the state newspaper, Number 4; 1919; chapter 1, verse 2.

Knowing:

The Surakarta regent's report letter on February 19, 1920, Number 913/2 B, with a statement that Trunodikromo A. had granted the right to row the land in Kampung Tipes along with its earth produce to Pododikromo.

Considering there were no problems, the request was granted.

Now I allow Pododikromo to ransack state-owned land in Kampung Tipes

Tipes District

Serengan Electricity

The district of the city, Surakarta Regency, covers 679 square meters, as stated in the letter of the size attached to this pikukuh letter, with the agreement that has been contained or will be contained in the state regulation on housing in the state of Surakarta.

This pikukuh letter was given to Pododikromo as a guide in the rowing of the land. 
Determination of bustle on March 30, 1921.'

The data is quoted from SP Number 20 / 1B and shows the existence of local wisdom in the legal field by showing verbal expressions Angengeti layang pranatan kang kapacak ing layang kabar nagara [...] Considering the regulatory letter contained in the state newspaper [...],Anggalih ora ana pakewuhe [...] 'Consider there are no problems [...]' and anglilani $[\ldots]^{\prime}$ Allow [...]'. All of these verbal expressions as legal language prevailed at that time, more or less like the legal language prevailing at this time.

2) Ethical / polite authority

Authority in the field of ethics is reflected in verbal expressions in the form of the use of speech levels of communication by the king to the people and society to the king [8]. For example:

[...]ne Mujinem kamot layang palapurane lurah Kampung Tipes katitimasan kaping: 5 Oktober 1940, Angka: 369/D8, surasane nyuwun anggadhuh mawa wewenang andarbeni palemahan kagungane nagara Angka: 413, minutblat 4a, seksi: $\mathbf{C}$, ing wewengkon Kalurahan Tipes, Onderdhistrik Serengan, sajroning kutha Surakarta.

'[...] Mujinem is contained in a letter from the village chief of Tipes on October 5, 1940, Number: 369 / D8, containing a request to row with the right to own state-owned land Number: 413, minutblat 4a, section: $C$, at the area of the Tipes sub-district, Serengan District, of Surakarta. '

The data is quoted from Andarbeni Authorities, Figures: 428/285 A.Z./PI 'Decision on Ownership, Number: 428/285 A.Z./PI. The use of a level of speech that reflects the principle of manners is reflected in the use of the word asking (Krama Andhap) 'application to quarrel', belonging to 'belonging' (the Old Man). The application is submitted to the country (the king as ruler) and then uses the word plead; and the land in question belongs to the state or the king and thus uses the word belonging to him. Therefore, the use of such words indicates the presence of local ethics / ethics.

3) Social authority

Social authority in the SP can be expressed by the use of verbal expressions pagaweyan tumrap nagara 'state work' and pagaweyan tumrap sagegolonganing kalurahan kampung 'The work usually done in the village kelurahan 'is as follows.

Sajrone Somowirono .......... kaparingan wawenang anggadhuh papan pomahan kang kapratelakake ing layang pikukuh iki, ditamtokake kena pagaweyan nagara, kaya ta:

a. Pagaweyan tumrap nagara kang kadhawuhake kamot ing layang pranatan.

b. Pagaweyan tumrap sagegolonganing kalurahan kampung, kang laku-lakune mranatani pagaweyan bakal ditetepake saka rembuge kalurahan kampung kene, dene manawa ora bisa kalakon, panewu pangreh praja kang ambawahake kang diwajibake agawe pranataning pagaweyan sagegolonganing kalurahan kampung mau.

'As long as Somowirono was given the right to row into housing land which was stated in this pikukuh letter, he was required to assist state work, such as:

a. The state's work is as stated in the regulation letter.

b. The work that is usually done in the village kelurahan, where the rules of the work will be determined from the results of the village kelurahan deliberations here, whereas if it cannot be done, the panewu pangreh praja that oversees it is obliged to make work regulations that apply in the village. ' 
Each right holder has an obligation to perform work duties for the benefit of the state and the community in accordance with established rules and occupations of the village villages and their decisions based on the results of their respective village council deliberations.

4) Field / location authority

The authority of the location is always included in the SP, so the ownership of rowdy rights becomes clear with the land and / or buildings owned by other people [9]. For example, SP Number 119, owned by Citrosuharto alias Sukardi, covering an area of 392 M2, shows boundaries with other people's land, namely Land Number 117 owned by M.Ng. Noyowirongko alias Sukiman, Land Number 118 owned by Citrosuharto alias Sukardi, Land Number 120 owned by Kromokretiko, and Land Number 121 owned by Joyosukarto.

The boundaries of the land owned by Citrosuharto aliyas Sukardi with those of others are limited by signs in the form of "iron barriers" and "stone platforms". Thus, the boundary between one and the other is very clear.

5) Authority of agricultural products

Local authority in the field of agricultural products is also included in the SP by mentioning directly with the lingual unit angrebegi sakarangkitrine 'all plants and their yields' [10]. Thus, the SP not only emphasizes the name of the owner, land area, boundaries, taxes, buildings that are on the land, but also highly respects the overall plants and crops on the land. This can be noted in SP Number 946/2 A, published by the Surakarta Palace, which belongs to Salamah.

Griya-griya dalah pasiten gadhuhanipun Jayawireja estri, ingkang kalilahaken, angebregi sakarangkitrine dhumateng Salamah, kawrat serat pratandha punika dereng kajangjekaken dhumateng sanesipun, saha sampun boten wonten pakewedipun, mirid wujudipun pasiten murwat regi f 400 (kawan atus rupiyah).

'Mrs Jayawireja's houses and land, which were handed over along with all plants and their produce to Salamah, contained in this pikukuh letter have not yet been bound by anyone's agreement, and there is no disturbing matter, paying attention to the existence of land worth regi $\mathbf{f} 400$ (four hundred rupiahs) ). '

6) Local authority in the tax sector

Local wisdom in the tax sector is always mentioned in every SP. The people are not only given the right to land for land, they also have the obligation to pay taxes to the state (kingdom or temple) each year. For example:

Somowirono, ............ saben taun kudu angladekake dhuwit pajeg marang praja Mangkunagaran, lumantar abdi dalem martanimpuna kang ambawahake, lumadine dhuwit mau kang saparo kudu kalakon kasep-kasepe ing surya kaping 30 Juni, sarta kang saparo kudu kaladekake kasep-kasepe ing surya kaping 31 Dhesember, dene kehing pajeg, lan tumapake wewangene anggone ambayar pajeg mau, bakal katamtokake ana ing layang kohir lan kapratelakake ing layang pajeg.

'Somowirono, ............. each year must pay taxes to the kingdom of Mangkunagaran, through the Martanimpuna servant who oversees it, submission of the tax money which is half must be paid no later than June 30, and the other half must to be paid no later than December 31, while the amount of tax, and the due date of the tax payment, will be determined in the final letter and stated in the tax letter. '

SP Data Number 335 issued by Pura Manngkunegaran shows that there is an obligation of the land owner of land rowdy to pay tax annually to the Martanimpuna in charge. Payments are made twice, half are paid no later than June 30, and the other half must be paid no later 
than December 31. Thus, the owner of rowdy rights has an obligation to the state (Pura Mangkunegaran) to pay taxes in accordance with the provisions of the kohir and tax returns. Society has a responsibility to the state, in this case paying taxes.

\section{b. Benefits of Local Authority in SP}

Local wisdom contained in the SP is very useful for today's society, especially the Javanese community in behaving in social and state life [11]. Awareness of the law is shown by the existence of rowdy rights (which is now referred to as Ownership Rights) on land that is recorded as very important to have because the SP (Certificate) is legally valid proof [12].

Awareness of ethics is very important in community and state life, because with ethics (manners) in this life there will be awareness of their respective positions, as rulers or as ordinary people [13]. This awareness will make life harmonious and conducive [14]. Likewise, social awareness will make this life will help and need one another [15]. Social life also brings to the awareness of its responsibilities to work for the state and society in general, including paying taxes to the state [16]. With the tax on the running of the government and the country's development going well, welfare will be increasingly felt by the community as a whole [17].

Awareness of the location / location of the land will provide a complete understanding of the ownership of rowdy rights, there will be no seizure of the territory because the boundaries are clear and the owner around his land is also mentioned the number and name of the owner [18].

Local authority of agricultural products made the Javanese people aware that their land was not only for housing, but also needed to be cultivated in order to provide useful results for their lives [19]. An inch of land is very useful in this life, by planting plants that benefit the owner of the land itself and for others in the vicinity [20] [21].

\section{Conclusion}

Based on the above data analysis, the following conclusions can be drawn.

a. SP contains Javanese local authority in the form of local wisdom in the field of law, the field of ethics / manners, the social field, the field of location / location of land, the field of agricultural produce, and the tax sector.

b. The local authority contained in the SP is very beneficial for the Javanese community, especially in social and state life so that they are aware in the legal, ethical, social, and awareness aspects of paying taxes.

c. SP in this life is very useful for students who conduct research in the field of land and the field of language or linguistics, for rowdy owners and their heirs in order to give rights and sell them to others; and the government (specifically the National Land Agency in the context of recording community land and other interests).

\section{References}

[1] Abdul Chaer. Linguistik Umum. Jakarta: Rineka Cipta, 2003.

[2] Anton M. Moeliono (Penyunting Penyelia). Kamus Besar Bahasa Indonesia. Jakarta: Departemen Pendidikan dan Kebudayaan dan Balai Pustaka, 1990.

[3] Sutopo, HB. Metode Penelitian Kualitatif, Surakarta: Universitas Sebelas Maret Press, 1998.

[4] Yohanes Suwanto, Dyah Padmaningsih, dan Endang Tri Winarni. "Tindak Tutur Dalam Serat 
Pikukuh (Kajian Pragmatik)”. (Laporan Penelitian Fundamental). Surakarta: Fakultas Ilmu Budaya Universitas Sebelas Maret, 2017.

[5] Yohanes Suwanto, Dyah Padmaningsih, dan Endang Tri Winarni. "Hak dan Kewajiban Raja dan Rakyat dalam Serat Pikukuh (Kajian Pragmatik)”. (Laporan Penelitian Mandiri Aktif). Surakarta: Fakultas Ilmu Budaya Universitas Sebelas Maret.

[6] D. Edi Subroto. Pengantar Metode Penelitian Linguistik Struktural. Surakarta: Sebelas Maret University Press, 1992.

[7] Departemen Pendidikan dan Kebudayaan. Bahasa Daerah di Indonesia. Jakarta: Bidang Bahasa, Pusat Pembinaan dan Pengembangan Bahasa, 1981.

[8] Sutopo, HB. Metode Penelitian Kualitatif. Surakarta: UNS Press, 1996.

[9] Sudaryanto (ed.). Tata Bahasa Baku Bahasa Jawa. Yogyakarta: Duta Wacana University Press, 1991.

[10] Sudaryanto. Metode dan Aneka Teknik Analisis Bahasa: Pengantar Penelitian Wahana Kebudayaan secara Linguistis. Yogyakarta: Duta Wacana University Press, 1993.

[11] Moleong, Lexy J. Metode Penelitian Kualitatif Edisi Revisi, Bandung: PT. Remaja Rosdakarya, 2015.

[12] Departemen Pendidikan dan Kebudayaan. Kebudayaan. (Majalah Nomor 01 Tahun I 1991/1992). Jakarta: Departemen Pendidikan dan Kebudayaan, 1991.

[13] Spradley, James P. Metode Etnografi. Yogyakarta: Tiara Wacana, 1997.

[14] Dove, Michael R. "Pengumpulan dan Penyusunan Data dalam Penelitian Antropologi". dalam Majalah Ilmu-ilmu Sastra Indonesia. Jakarta: Fakultas Sastra Universitas Indonesia, 1981.

[15] Edi Subroto dan Soewito. Pengantar Metode Penelitian Linguistik Struktural. Surakarta: Sebelas Maret University Press, 1992.

[16] Harimurti Kridalaksana. Kamus Linguistik. Jakarta: PT Gramedia, 1984

[17] Lyons, John. Semantics II. Cambridge: Cambridge University Press, 1977.

[18] Rais, Wakit A., Kearifan Lokal dalam Bahasa dan Budaya Jawa: Studi Kasus Masyarakat Nelayan di Pesisir Selatan Kebumen Jawa Tengah (Kajian Etnolinguistik). Surakarta: UNS Press, 2017.

[19] Shri Ahimsa Putra, H. (tanpa tahun). "Bahan Kuliah Epistimologi Anthropologi". Yogyakarta: Program Pasca Sarjana UGM.

[20] Shri Ahimsa Putra, H. "Etnolinguistik: Beberapa Bentuk Kajian". Makalah. Yogyakarta: Balai Penelitian Bahasa, 26-27 Maret 1997.

[21] S.T. Widodo and K. Saddhono. "Petangan Tradition In Javanese Personal Naming Practice: An Ethnoliguistic Study." GEMA Online ${ }^{\circledR}$ J. of Lang. Stu. vol. 12 no. 4 pp 1165-1177, 2012 